\title{
Heterogenized Metallophthalocyanines for Photodynamic Microorganism Inactivation: an Overview of our Experience
}

\author{
Nina A. Kuznetsova, ${ }^{\circledR}$ and Oleg L. Kaliya \\ Organic Intermediates and Dyes Institute, 123995 Moscow, Russia \\ @ Corresponding authorE-mail:lab32@niopik.ru
}

\begin{abstract}
Heterogeneous systems synthesized by grafting of phthalocyanines to aminopropyl silica gel can exhibit high photobactericidal and photovirucidal activity. In this review, recent works of Russian group in the field are summarized. Ways to achieve low aggregation degree and high ability in singlet oxygen generation for immobilized phthalocyanine as well as effects of charge of attached phthalocyanine, support pore size, length of spacer between dye and silica upon efficacy of heterogeneous sensitizers in photodynamic microorganism inactivation are considered.
\end{abstract}

Keywords: Phthalocyanine, heterogeneous sensitizer, microorganism, photodynamic inactivation.

\section{Гетерогенизированные фталоцианины Аля фотодинамической инактивации микроорганизмов: обзор наших работ}

\author{
Н. А. Кузнецова, ${ }^{@}$ О. ᄉ. Калия
}

Федеральное государственное унитарное предприятие «Научно-исследовательский институт органических полупродуктов и красителей» (ФГУП ГНЦ «НИОПИК»), 123995 Москва, Россия

@E-mail:lab32@niopik.ru

\begin{abstract}
Гетерогенные системы, синтезированные ковалентной прививкой фталочиианинов к аминопропилированному силикагелю, могут проявлять высокую фотобактерицидную и фотовирулицидную активность. В обзоре обобщены недавние работы нашей группь в этой области. Рассмотрень подходы к достижению низкой степени агрегаџии иммобилизованного фталоцианина и высокого выхода генерации им синглетного кислорода, а также данные о влиянии заряда фталоцианина, размера пор носителя, длины спейсера, связывающего краситель с силикагелем, на эффективностьгетерогенного сенсибилизаторав фотодинамической инактивации микроорганизмов.
\end{abstract}

Ключевые слова: Фталоцианин, гетерогенный сенсибилизатор, микроорганизм, фотодинамическая инактивация. 


\section{Introduction}

Singlet oxygen-mediated photooxidation reactions are attractive for the development of new technologies for water treatment in order for decontamination of organic pollutants and germs. ${ }^{[1-3]}$ Such processes meet environmentally friendly or "green" chemistry demands, taking into account use of visible light (solar radiation), oxygen (from air) as oxidant in a presence of photosensitizer. Photosensitization is a simple method for the production of singlet oxygen $\left({ }^{1} \mathrm{O}_{2}\right)$, when ${ }^{1} \mathrm{O}_{2}$ is generated via an energy transfer from the sensitizer (as a rule, dye) in excited triplet state to the ground-state (triplet) oxygen: ${ }^{[4,5]}$

$$
\begin{aligned}
& { }^{1} \mathrm{~S}_{0} \stackrel{h v}{\longrightarrow}{ }^{1} \mathrm{~S}^{*} \rightarrow{ }^{3} \mathrm{~S}^{*} \\
& { }^{3} \mathrm{~S}^{*}+{ }^{3} \mathrm{O}_{2} \rightarrow{ }^{1} \mathrm{~S}_{0}+{ }^{1} \mathrm{O}_{2} \\
& { }^{1} \mathrm{O}_{2}+\mathrm{Subs} \rightarrow \mathrm{Subs}_{(\mathrm{ox})}
\end{aligned}
$$

where ${ }^{1} \mathrm{~S}_{0},{ }^{1} \mathrm{~S}^{*}$ and ${ }^{3} \mathrm{~S} *$ are molecules of photosensitizers in the ground and excited singlet and triplet states; Subs substrate for oxidation.

Singlet oxygen has high oxidation ability. Being an electrophilic agent, it oxidizes unsaturated double bonds, sulfide, phenolic, amino groups, and other electron-donor groups in organic compounds. ${ }^{[6-8]}$ Singlet oxygen reacts with many types of biomolecules, such as proteins, nucleic acids and lipids, leading to cell death. ${ }^{[9,10]}$ In aqueous media the homogeneous and heterogeneous sensitizers are employed. Homogeneous photosensitizers are water-soluble, UV-vis absorbing molecules that have singlet oxygen generating ability. A recent review ${ }^{[11]}$ provides the overview of sensitizers, applicable for water solutions. However, for use in water purification the immobilization of singlet oxygen photosensitizers onto the solid support is a desirable approach since the photosensitizer may be easily separated from the reaction medium and reused. Moreover, binding of the sensitizers to carriers may result in advantageous sensitizer disaggregation, since aggregation promotes the non-radiative internal conversion, causing a shortening of the triplet lifetime and a drastic reduction in the overall efficiency of ${ }^{1} \mathrm{O}_{2}$ production.

Historically, the first reference on synthesis and photobactericidal action of the heterogeneous sensitizer of singlet oxygen formation is dated to 1973. ${ }^{[12]}$ The reagent consisted of dye, Rose Bengal, covalently bound to an insoluble poly(styrene-divinylbenzene) matrix. Suspension of this compound inactivated $E$. coli cells upon light exposure (99.99 \% inactivation was achieved in 1-2 h). Since then, the potential of heterogeneous singlet oxygen sensitizers against microorganisms was not exploited for several decades due to the discovery of antibiotics and poor response of some well known pathogens, especially Gram-negative bacteria, to photoinactivation with traditional photosensitizing agents. Nevertheless, during the past two decades interest to photodynamic inactivation of microorganisms in water and biological fluids, including use of heterogeneous singlet oxygen sensitizers, was renewed mostly due to emergence of antibiotic resistant pathogens. ${ }^{[13]}$ Thus, recently the photobactericidal activities of some heterogeneous systems, such as bound to silica gel and cellulose porphines, ${ }^{[14,15]}$ porphyrin and phthalocyanine photosensitizers incorporated into chitosan, ${ }^{[16]}$ tetracationic porphyrin encapsulated within silica microparticles, ${ }^{[17]}$ polyazaheterocyclic $\mathrm{Ru}^{\mathrm{II}}$ coordination compound adsorbed at porous silicone, ${ }^{[18]}$ a suspension of fullerene $\mathrm{C}_{60}{ }^{[19]}$ were tested.

The present paper is an overview of our recently published experimental studies on the microorganism inactivation in aqueous media with new heterogeneous sensitizers, based on bound to silica phthalocyanines (Pcs). The derivatives of $\mathrm{Zn}, \mathrm{Al}$, Si phthalocyanines, known as efficient homogeneous singlet oxygen sensitizers, ${ }^{[20,21]}$ were used as active phase on silica support. An important advantage of Pcs is the intense absorption of the light in the range of solar terrestrial spectrum. Effects of such factors as phthalocyanine structure, dimensions of silica gel pores, spacer length between $\mathrm{Pc}$ and silica gel support upon absorption and emission spectra, efficacy of singlet oxygen generation and photobiocidal activity of heterogeneous sensitizers are presented.

\section{Design of Heterogeneous Sensitizers}

\subsection{Phthalocyanines as an Active Phase}

Phthalocyanine molecules are composed of four isoindole subunits linked by nitrogen atoms (Figure 1).

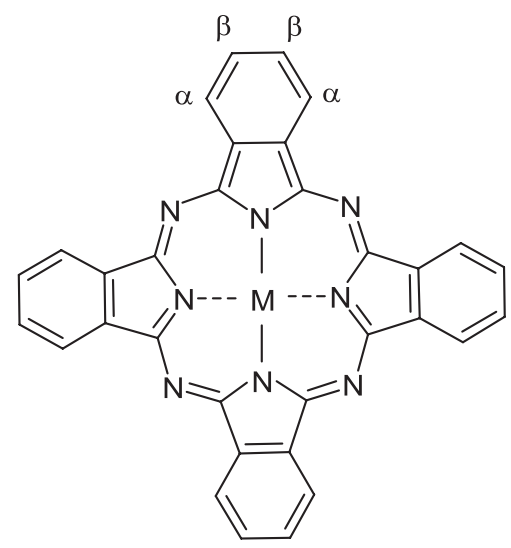

Figure 1. The structure of metallophthalocyanine.

These compounds possess extensively conjugated system, which determines their intense blue-green color and light-harvesting properties. Phthalocyanines form complexes with most elements of periodic system. Due to strong $\pi-\pi$ interaction and the flatness of the aromatic core, they are prone to aggregation. ${ }^{[1]}$ However the formation of dye aggregates decreases the efficiency of ${ }^{1} \mathrm{O}_{2}$ photogeneration. Physical properties of phthalocyanines including tendency to aggregation and singlet oxygen yield can be optimized by substitution of the phthalocyanine ring at $\alpha$ and $\beta$ positions or by changes in the central metal or axial ligands.

\section{Modification of the Central Metal and Axial Substitution}

It is well known that photophysical properties of $\mathrm{Pc}$ complexes are strongly dependent on the central atom. ${ }^{[22]}$ The metal free phthalocyanines show low ability to 
sensitize singlet oxygen formation, as do phthalocyanines of paramagnetic metals. High triplet state quantum yields and long triplet lifetimes are required for efficient photosensitization, and these criteria may be fulfilled by the incorporation of diamagnetic metals such as zinc, gallium, indium, aluminum or silicon into the phthalocyanine macrocycle. ${ }^{[20]}$ In order to increase the quantum yield of singlet oxygen, the heavy-atom effect based on spin-orbit coupling, which can increase the $\Phi_{\mathrm{T}}$ value, is generally employed also. Thus, molecular design of optimized photosensitizers is restricted by diamagnetic, advisably heavy metals, in Pc core. In our work the derivatives of zinc, aluminum and silicon phthalocyanines were used as active phase of heterogeneous sensitizers. Aluminum and silicon phthalocyanines have axial ligands on centrally chelated ions and in this way tackle unfavorable aggregation on the surface of support. Zinc phthalocyanines do not possess any axial ligand, however owing to the heavy metal in the core provide high yield of singlet oxygen generation.

\section{Macrocycle Substitution}

It is generally accepted that in the majority of cases it is the aggregation of photosensitizer that decreases the yield of singlet oxygen formation. One of the means to suppress the stacking of Pcs on the support is the introduction of bulky groups at $\alpha$ and $\beta$ positions of the four benzene rings. Synthesized in our work heterogeneous systems as active phase mostly have metallophthalocyanines with positively charged $N$-(2-hydroxyethyl)- $N, N$-dimethylammoniummethyl ramified substituents at peripheral $\beta$ positions (MPc1, Figure $2 \mathrm{~A})$. It should be noted that positively charged sensitizers are of particular interest, because their photobiocidal activity is markedly higher than that of negatively charged or neutral ones. ${ }^{[23-26]}$ This may be due to more effective interaction of the negatively charged bacteria outer membrane with positively charged dye. ${ }^{[27]}$

Non-peripheral $\alpha$ substitution of phthalocyanines offers the sensitizers with still lower aggregation tendency. [28,29] Therefore, to diminish aggregation further, four phenylsulphanyl fragments were introduced at $\alpha$ positions of MPc2-MPc4 (Figure 2B). Out of plane phenylsulphanyl groups endow phthalocyanines with low tendency to aggregation.

\subsection{Support}

There is increasing interest in using silica (S) as support of photosensitizers. Silica can be prepared with large surface area and modulated porosity, modified with aminopropyl groups (p), to which molecules may be chemically bonded. Aminopropyl silica (S-p) is commercially available and widely used for this purpose. For phthalocyanine grafting we utilized the aminopropyl silica gels with pore sizes 10,25 and $75 \mathrm{~nm}$ (supports S10-p, S25-p and S75-p, correspondingly).

The synthesis ${ }^{[30]}$ included at the first step chloromethylation of phthalocyanines, followed by reaction of obtained polychloromethyl derivatives with the amino functions on the aminopropyl silica. Chloromethylation yielded phthalocyanines containing on average 8 chloromethyl groups. Also, it was found that substitution of tetraphenylsulphanylphthalocyanine was directed not to the phthalocyanine core but to the phenyl pendants. This is evidenced by difference in chemical shifts of methylene protons of the chloromethyl group: $\delta=5.0 \mathrm{ppm}$ for $\mathrm{CH}_{2} \mathrm{Cl}$ protons in
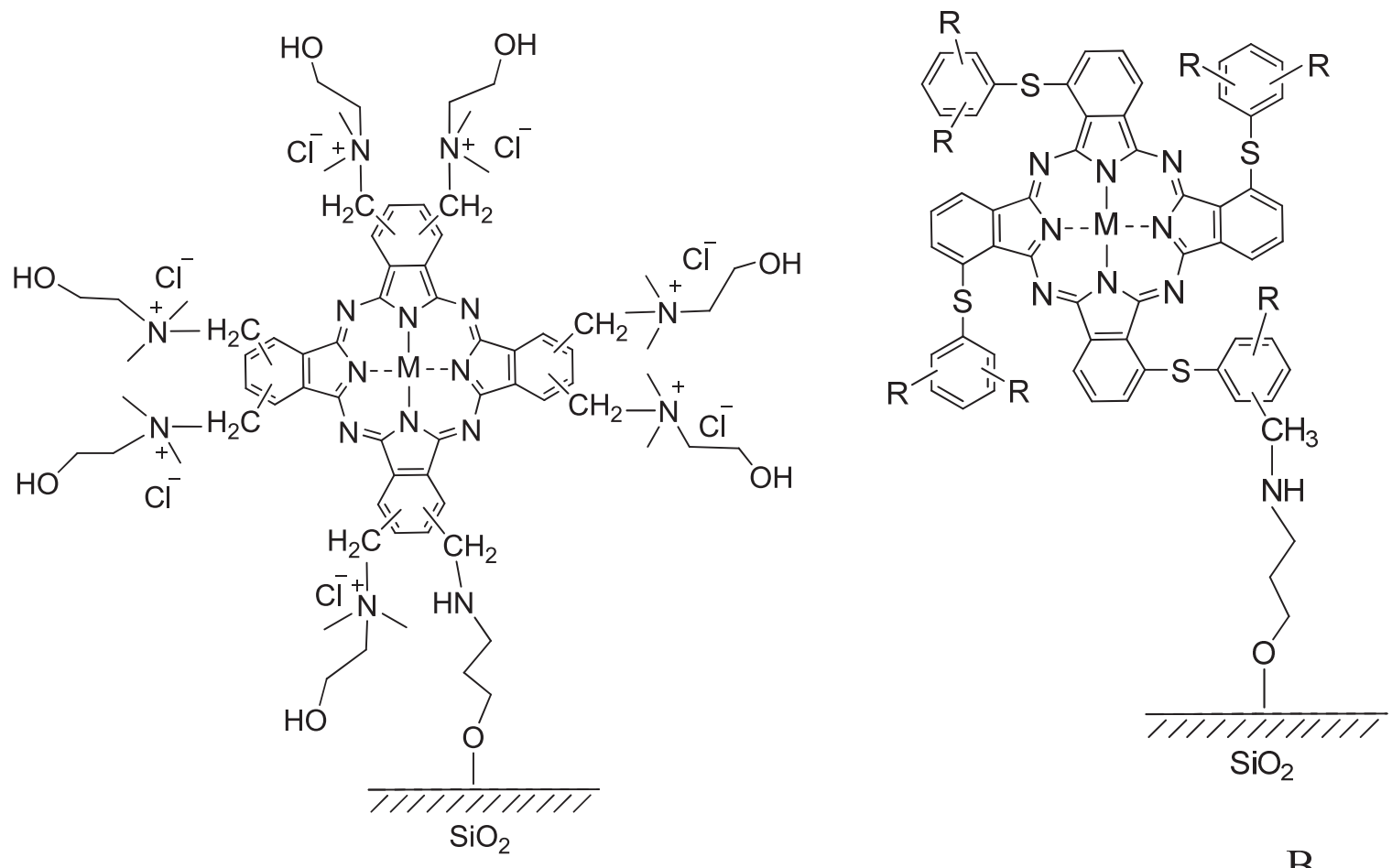

A

B

Figure 2. Structure of heterogeneous sensitizers: S-p-MPc1 (A), S-p-MPc2 (B, R $\left.=\mathrm{CH}_{2} \mathrm{Cl}\right)$; S-p-MPc3 $\left(\mathrm{B}, \mathrm{R}=\mathrm{CH}_{2}-\mathrm{N}^{+}\left(\mathrm{CH}_{3}\right)_{2}^{-}\right.$ $\mathrm{CH}_{2} \mathrm{CH}_{2} \mathrm{OH}$ ); S-p-MPc4 (B, $\mathrm{R}=\mathrm{CH}_{2}-\mathrm{NH}-\mathrm{CH}_{2} \mathrm{CH}_{2} \mathrm{SO}_{3}{ }^{-} \mathrm{Na}^{+}$). 
chloromethylated tetra-phenylsulphanylphthalocyanine, and $\delta=5.5-5.8 \mathrm{ppm}$ for protons of $\mathrm{CH}_{2} \mathrm{Cl}$ groups connected with the phthalocyanine ring.

Covalent binding ${ }^{[30]}$ of the chloromethyl substituted Pcs to amino groups of aminopropyl silica was carried out smoothly in $N, N^{\prime}$-dimethylformamide at $80-85^{\circ} \mathrm{C}$. The complete decolouration of solutions after $0.5-1 \mathrm{~h}$ evidenced all phthalocyanine molecules were consumed in the reaction. Simultaneously, aminopropyl silica with attached phthalocyanine molecules gained deep green colour. Similar treatment of silica without aminopropyl groups gave only slight coloration of granules and the Pc mainly remained unattached in the solution. These observations clearly show that Pc grafting includes the interaction of chloromethyl groups of Pc with amino groups of aminopropyl silica. We believe that binding involves one or at the most, two chloromethyl groups per Pc molecule. The immobilized sensitizer still bears few intact chloromethyl groups, susceptible to modification under treatment with various amines. Thus, the reaction of the immobilized chloromethyl substituted phthalocyanines with $N, N$-dimethylaminoethanol yields derivatives with positively charged $N$-(2-hydroxyethyl)- $N, N$-dimethylammoniummethyl groups (MPc1 and MPc3, Figure 2). Scheme 1 as an example represents the preparation of the aminopropyl silica gel-supported MPc3. Treatment of immobilized chloromethyl substituted tetra-phenylsulphanylphthalocyanine (MPc2) with sodium taurinate caused formation of the immobilized phthalocyanine derivative MPc4, having negative charge. Thus, the complete set of synthesized heterogeneous systems included immobilized phthalocyanines with negative and positives charges and the initial non charged chloromethyl substituted phthalocyanine (Figure 2). Loading of the support by the phthalocyanine derivatives varied in the range $1.5-10 \mu \mathrm{mol} \cdot \mathrm{g}^{-1}$.

So far the heterogeneous systems with dye molecules tethered to silica through one propyleneimine spacer (structures S-p-MPc) were considered. In search of sensitizers with improved photobactericidal activity, aminopropyl silica was modified by repeated treatment with 3-bromopropylamine hydrobromide to lengthen chain, connecting phthalocyanine with support. ${ }^{[31]}$ Using supports, modified in this way, series of new heterogeneous sensitizers have been synthesized by grafting of phthalocyanines to silica by spacers of variable length. One- and three-fold treatment of the aminopropyl silica with 3-bromopropylamine gives chains of two and four propyleneimine fragments ( $2 p$ and $4 p$ spacers). Example for synthesis of S-4p-SiPc1 is given in Scheme 2. It should be mentioned that an attachment of propylamine residues in reaction with bromopropyl amine hydrobromide and chloromethylated phthalocyanines to oligoaminopropyl silica is possible both to primary and secondary amino group of $2 p$ or $4 \mathrm{p}$ spacer. However, considering the steric reasons, the participation in reaction of terminal primary one will be preferable (as shown for example on Scheme 2). Three series of the sensitizers have been synthesized: first series included $\mathrm{SiPc}$, anchored to $\mathrm{S} 25$ by one, two and four propyleneimine groups (S25-p-SiPc1, S25-2p-SiPc1, S25-4p-SiPc1), in the second series S75 was used as support (sensitizers S75-pSiPc1, S75-2p-SiPc1, S75-4p-SiPc1, accordingly), and third one consisted of S25-p-AlPc3 and S25-2p-AlPc3. Thus, a set of heterogeneous sensitizers with positively charged photosensitizing agents tethered to silica by spacers of variable length have been synthesized.

\section{Physicochemical Properties and Singlet Oxygen Generation}

The absorption spectra, fluorescence and singlet oxygen generation of the immobilized phthalocyanines were studied for suspensions of heterogeneous sensitizers in glycerol.

As can be seen from Figures 3 and $4,{ }^{[30]}$ the absorption spectra of immobilized $\mathrm{ZnPc} 3$ and AlPc3 are broadened when compared with those of solutions. Broadening of the absorption bands is typical for many supported dyes. This effect can be attributed to the perturbation of phthalocyanine molecule electronic structure by interaction with the carrier. Increase of AlPc3 loading did not lead to noticeable spectrum change. However with the increase of loading from 1.5 to 10 $\mu \mathrm{mol} \cdot \mathrm{g}^{-1}$, the $\mathrm{Q}$ band of $\mathrm{ZnPc} 3$ was gradually shifted to the red (Figure 3) that might indicate the partial aggregation of dye molecules. Nevertheless, absorption spectra of immobilized phthalocyanines have an intense absorption band Q with a vibration satellite in the short-wavelength region. Such

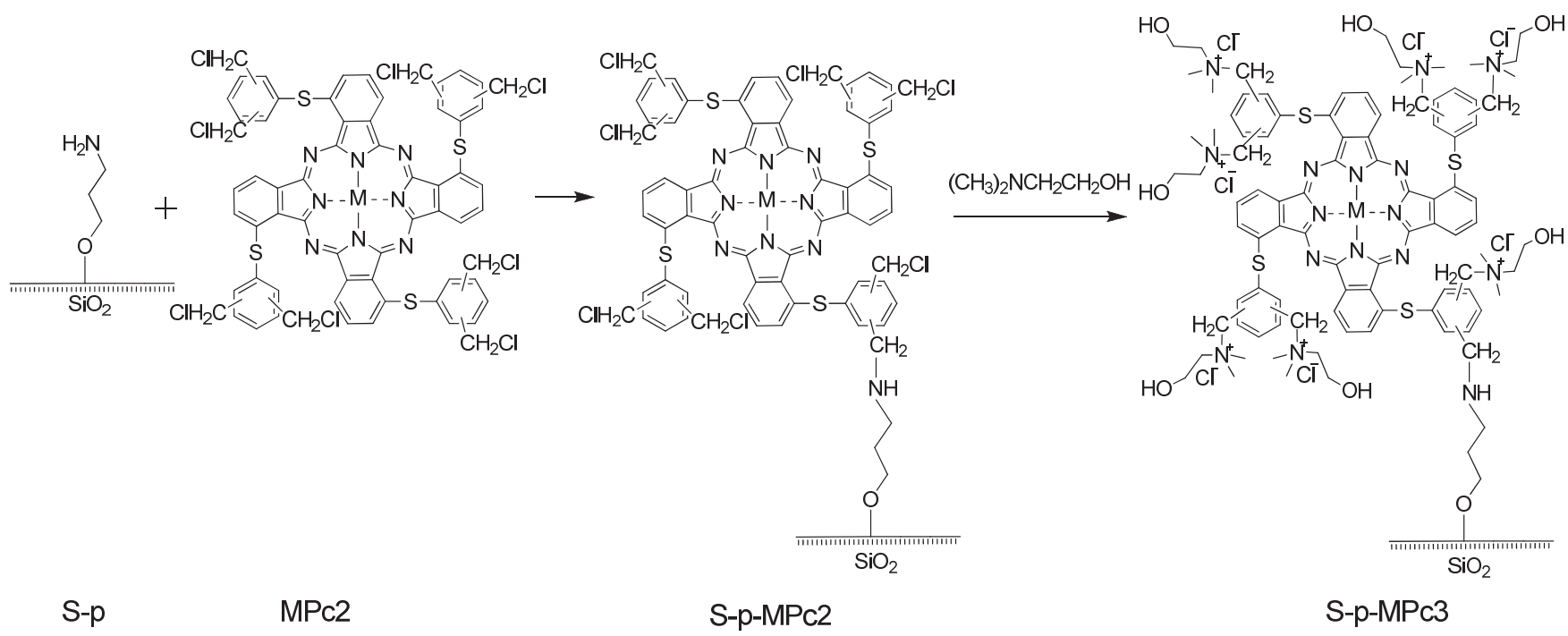

Scheme 1. Synthesis of the aminopropyl silica gel-supported MPc3. 


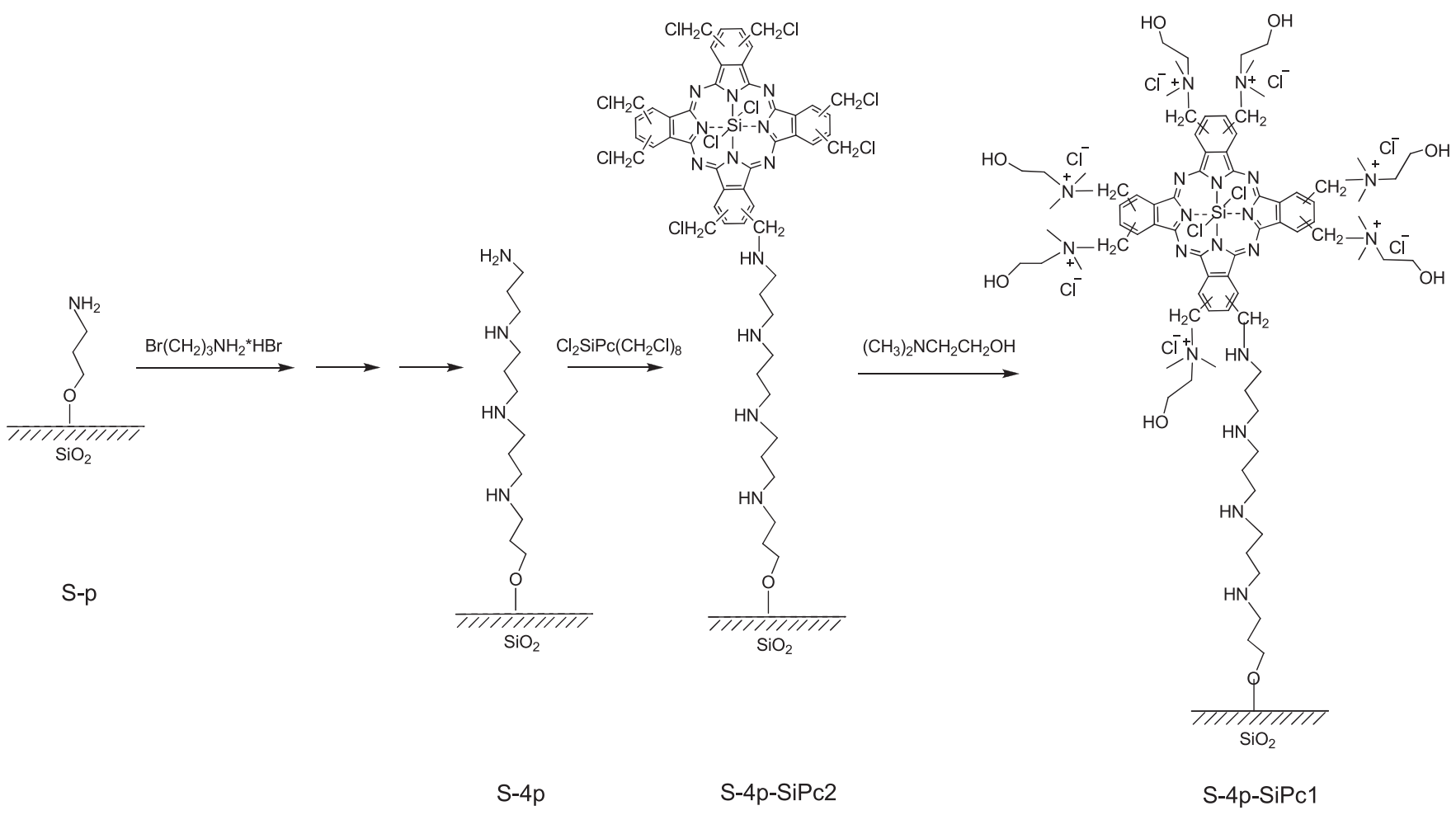

Scheme 2. Synthesis of the S-4p-SiPc1 and S-4p-SiPc2.

a character of the spectrum indicates the high content of photochemically active monomers in the active phase.

Sensitizers S25-p-AlPc3 and S25-p-AlPc4 were synthesized from the same precursor, namely S25-pAlPc2, by substitution of chlorine in the chloromethyl groups on positively charged $N$-(2-hydroxyethyl)- $N, N$ dimethylammoniomethyl or negatively charged taurinyl residues. ${ }^{[30]}$ Therefore it is not surprising that the absorption spectra of these sensitizers showed great semblance (Figure 4), which points to the identical distribution of the sensitizer molecules over the surface of the support.

SiPc1, bound to silica gel by spacers of variable length, showed low broadening and absence of spacer length effect upon phthalocyanine absorption spectrum. ${ }^{[31]}$ Immobilized

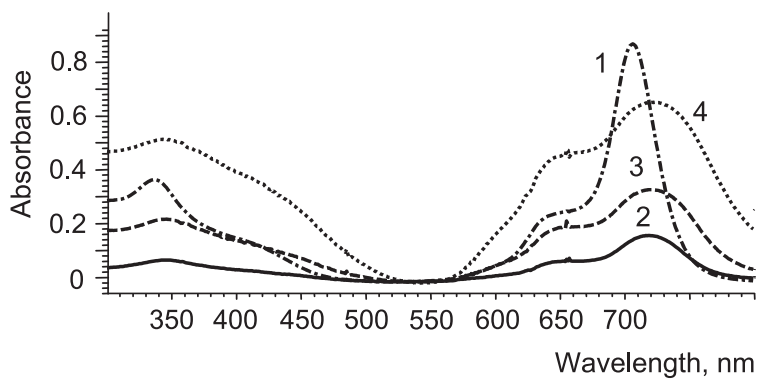

Figure 3. Electronic absorption spectra of $\mathrm{ZnPcl}$ in water (1) and glycerol suspensions $\left(4 \mathrm{~g} \cdot \mathrm{L}^{-1}\right)$ of S25-p-ZnPcl: (2) - loading $1.5 \mu \mathrm{mol} \cdot \mathrm{g}^{-1}$, (3) - $3 \mu \mathrm{mol} \cdot \mathrm{g}^{-1}$ and (4) - $10 \mu \mathrm{mol} \cdot \mathrm{g}^{-1}$. Reproduced with permission from: New heterogeneous photosensitizers with phthalocyanine molecules covalently linked to aminopropyl silica gel. N.A. Kuznetsova, O.A. Yuzhakova, M.G. Strakhovskaya, A.O. Shumarina, A.S. Kozlov, A.A. Krasnovsky, O.L. Kaliya. J. Porphyrins Phthalocyanines 2011, 15, Issues 7-8. Copyright (C) 2011 World Scientific Publishing Company. dye displays monomeric behavior - both maxima and shape of heterogeneous sample Q bands are very similar to those of free dye. Specific behaviour of SiPc1 is caused by axial ligands at central atom and ramified substituents preventing a close interaction with support and adjacent dye molecules.

Study of photosensitizers, in which the active phase, AlPc3, was covalently grafted to aminopropylated silica gels with different pore sizes, ${ }^{[32]}$ have shown that phthalocyanines cannot penetrate into small, less than 10 -nm pores. Access to the pores increases with the increase in the pore size, resulting in the active phase being located predominantly inside pores in samples having above 25 -nm pores. ${ }^{[32]}$ Interestingly, this is evidenced by the sensitizer colour (Figure 5): sample S75-p-AlPc3 (silica gel pores of $75 \mathrm{~nm}$, AlPc3 grafted as an

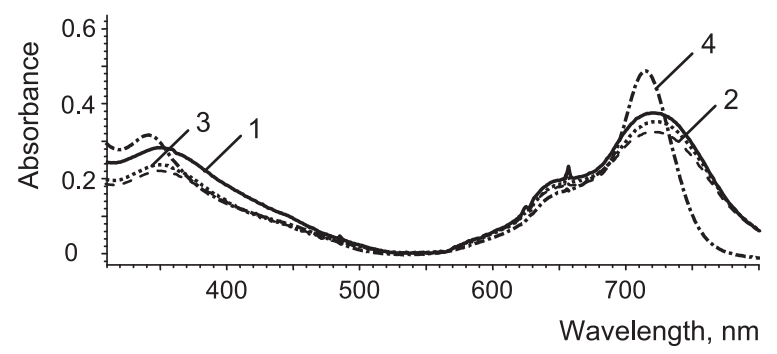

Figure 4. Electronic absorption spectra in glycerol (suspension 4 $\mathrm{g} \cdot \mathrm{L}^{-1}$ ) of S25-p-AlPc2 (1), S25-p-AlPc3 (2), S25-p-AlPc4 (3) and free AlPc3 in water (4). Reproduced with permission from: New heterogeneous photosensitizers with phthalocyanine molecules covalently linked to aminopropyl silica gel. N.A. Kuznetsova, O.A. Yuzhakova, M.G. Strakhovskaya, A.O. Shumarina, A.S. Kozlov, A.A. Krasnovsky, O.L. Kaliya. J. Porphyrins Phthalocyanines 2011, 15, Issues 7-8. Copyright (C) 2011 World Scientific Publishing Company. 


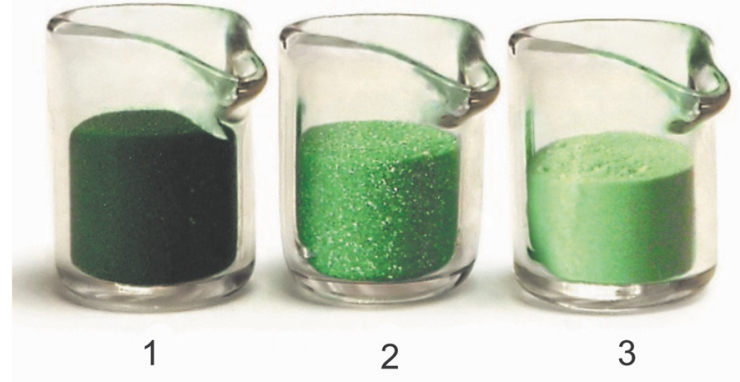

Figure 5. Sensitizers S10-p-AlPc3 (1), S25-p-AlPc3 (2) and S75p-AlPc3 (3) (Reproduced with permission from Ref. ${ }^{[32]}$ Copyright (C) Pleiades Publishing, Ltd., 2013).

active phase) is pale green, while S10-p-AlPc3 (10 nm pores) of the same phthalocyanine loading is dark green. Silica gel is transparent; however, the light is substantially reflected by its surface and does not penetrate the pores due to the high difference between light refraction coefficients of air and silica gel. Therefore, coloration is only due to the phthalocyanine located on the surface, and a more intensive coloration of samples with small pore sizes indicates the predominant location of AlPc3 on the surface of particles of such a silica gel. This conclusion is in agreement with the relative pore size and diameter of the AlPc3 molecule. The diameter of the AlPc3 molecule inclusive of bulky substituents is about 5 $\mathrm{nm}$. One may assume that these molecules penetrate poorly into the $10 \mathrm{~nm}$ pores having aminopropyl groups on the inner surface, further hindering the approach of the dye into the pores. The dye is mainly located on the support surface in this case. When the pore size increases to $75 \mathrm{~nm}, \mathrm{AlPc} 3$ molecules easily penetrate silica gel pores and uniformly distribute themselves over its entire internal and external surface. In this case, AlPc3 is predominately located inside the pores, the surface of which dominates. It is obvious that in order to ensure the effective penetration of the dye into the pores their diameter should be more than $20 \mathrm{~nm}$. Thus, the potential of heterogeneous systems, which differ not only in pore size, but in active phase localization, to inactivate bacteria and viruses were investigated.

It was observed that emission spectra of suspensions of heterogeneous sensitizers in glycerol were the mirror images of the long wavelength absorption maxima and the fluorescence excitation spectra showed all main phthalocyanine absorption bands. ${ }^{[30,32]}$ The light scattering hampered study of heterogeneous sensitizer fluorescence significantly, therefore only relative fluorescence quantum yields were evaluated. With $\mathrm{ZnPcl}$ as an active phase it was found that the relative fluorescence yield decreases with the increase in the concentration of dye on the support, which is apparently due to the increase in the fraction of aggregates. Thus, the increase of $\mathrm{ZnPc1}$ concentration from 1.5 to 10 $\mu \mathrm{mol} \cdot \mathrm{g}^{-1}$ resulted in four times reduction of the relative fluorescence yield.

It was found also, that quantum yield of fluorescence increased with the decrease in the silica gel pore size (at the same concentration of the dye). ${ }^{[32]}$ One may assume that the fluorescence corresponded mostly to Pc molecules distributed over the silica gel surface outside the pores. It is possible that the decrease in the observed fluorescence yield upon the increase in the pore size is due to the fact that, in this case, more and more phthalocyanine molecules are located inside the pores and emit fluorescence, which is reflected by their internal surface.

The length of spacer between phthalocyanine and support had little effect upon fluorescence efficiency. ${ }^{[31]}$

Energy transfer between the triplet state of photosensitizer and ground state molecular oxygen leads to the production of singlet oxygen, ${ }^{1} \mathrm{O}_{2}$, which is the key agent in the photodynamic action. Phthalocyanines, used for grafting, in solution displayed high singlet oxygen quantum yield and, when immobilized, retained the ability for singlet oxygen production. In our studies the production of singlet oxygen was tested by bleaching of singlet oxygen trap $(1,3-$ diphenylisobenzofuran, DPBF) in aqueous suspensions of heterogeneous sensitizers, containing $0.2 \mathrm{M}$ sodium dodecyl sulfate. The absorption of DPBF $\left(\lambda_{\text {max }}=414 \mathrm{~nm}\right)$ decreases quickly upon the irradiation of suspensions in the region of the attached phthalocyanine absorption maximum. Sodium azide, a singlet oxygen quencher, markedly reduced the rate of photosensitized oxidation of DPBF, confirming, therefore, the participation of singlet oxygen in the process.

It is essential to determine the efficacy of ${ }^{1} \mathrm{O}_{2}$ production. However, the methods, used for singlet oxygen quantum yield determination in homogeneous solutions, cannot be applied in a heterogeneous system, because the part of light absorbed by the sensitizer bound to support cannot be determined due to light scattering. Therefore, the relative ${ }^{1} \mathrm{O}_{2}$ yields were evaluated from kinetics of DPBF bleaching in identical conditions.

The relative studies show that aggregation of the supported dye inhibits singlet oxygen generation. For example, the increase from 1.5 to $10 \mu \mathrm{mol} \cdot \mathrm{g}^{-1}$ of the $\mathrm{ZnPc1}$ loading on the silica gel gives 4 times reduction of ${ }^{1} \mathrm{O}_{2}$ yield caused by growth of dye aggregation. ${ }^{[30]}$ The obtained results demonstrate an increase in the yield of singlet oxygen upon the reduction in the pore size, although this tendency is expressed more weakly than in the case of fluorescence. It seems that the generation of singlet oxygen is mainly provided by dye molecules located on the surface of the support rather than in its pores. ${ }^{[32]}$ The length of linker has no appreciable impact upon efficacy of singlet oxygen

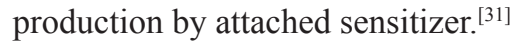

Since heterogeneous systems under consideration in this paper sensitize formation of singlet oxygen, the question of their stability to oxidation, particulally mediated by singlet oxygen (selfsensitization), arises. Below three possible pathways of sensitizer photooxidation are examined.

1. Photobleaching of attached phthalocyanine due to the ring chromophore degradation. Our study of free $\mathrm{ZnPc1}$, SiPc1 and AlPc3 in aqueous solution revieled their high photostability: photobleaching quantum yields were about $10^{-5}\left(\mathrm{ZnPc}^{[33]}\right)$ and lower ( $\mathrm{SiPc} 1$, AlPc3). And this is not surprising since positively charged substituents stabilize chromophore to oxidation by electrophylic singlet oxygen. In all our experiments with heterogenized phthalocyanines we did not observe their bleaching.

2. Phototransformation of substituents in the core. As will be shown below, promising heterogeneous sensitizers as 
active phase have phthalocyanines with stable against oxidation positively charged $N$-(2-hydroxyethyl)- $N, N$ dimethylammoniomethyl gropes. Suitable target for oxidation by singlet oxygen is thioether fragment. ${ }^{[34]}$ However it is well established by now that aromatic sulfides and thioethers exhibit low reactivity in reactions with singlet oxygen. ${ }^{[35]}$ Absence of shifting of the $\mathrm{Q}$ band maximum in the phthalocyanine absorption spectrum during irradiation gives an experimental indication of low efficiency of substituent phototransformation.

3. As it is known, singlet oxygen interaction with alkylamino group may lead to its oxidative $N$-dealkylation. ${ }^{[36]}$ Centered on NH group of oligopropylenamine spacer, this process will result in linker oxidative cleavage. Efficacy of bimolecular alkylamine dealkylation by singlet oxygen depends upon many factors, among them domination of physical singlet oxygen quenching by amines upon chemical quenching ${ }^{[36]}$ and low singlet oxygen lifetime in aqueous media are unfavorable. In fact, we did not observe release of phthalocyanine in solution after prolonged irradiation.

\section{Photodynamic Activity of Heterogeneous Sensitizers}

There are two basic mechanisms that have been proposed to account for the lethal damage caused to bacteria by photodynamic action: (i) DNA damage and (ii) damage to the cytoplasmic membrane, allowing leakage of cellular contents or inactivation of membrane transport systems and enzymes. ${ }^{[9]}$ Homogeneous sensitizers are accumulated by bacteria cells and so are able to damage bacteria efficiently by each of these mechanisms depending on sensitizer localization. However, when the photosensitizer is irreversibly bound to support by covalent bonding, it cannot penetrate deeply into cell. In this case the reactive oxygen species are generated outside bacteria and should to diffuse to it. The first target is outer cell membrane and so the prevalence of second mechanism is obvious. It should be noted also that in water the diffusion length of singlet oxygen, the main cytotoxic agent in photodynamic microorganism inactivation, is short, about $200 \mathrm{~nm} .^{[37]}$ Therefore the immediate proximity of the supported photosensitizer and microorganism is very important for efficient photodynamic disinfection of aqueous media.

Hereinafter our results on bacteria and virus photodynamic inactivation with use of heterogeneous sensitizers will be considered.

\subsection{Bacteria Photoinactivation}

In the most studies, the photoinactivation of genetically engineered bioluminescent strain E. coli (pXen7) (biosensor) was used by us to test the photobactericidal activity of heterogeneous sensitizers. This biosensor system known under the trade mark Ecolum is widely exploited for the assessment of the toxicity of various compounds. ${ }^{[23]}$ It was shown that photodynamic killing of bacterial cells caused reduction of the bioluminescence intensity. This effect was found to correlate linearly with the colony-forming ability of the biosensor cells. ${ }^{[23]}$ Thus, bioluminescence quenching serves also as a rapid and simple test for the assessment of the photocytotoxicity of dyes. ${ }^{[23]}$

The incubation of bacteria with the heterogeneous sensitizers under study in the absence of light did not lead to reduction of bioluminescence, evidencing that the sensitizers are nontoxic in the dark. Irradiation of biosensor suspensions in the presence of phthalocyanine-free silica gel did not affect bioluminescence either. At the same time, irradiation of bacteria in the presence of the heterogeneous photosensitizers rapidly suppressed bioluminescence as a result of photobactericidal effect.

Dependence of efficiency of biosensor photoinactivation on the structure of attached phthalocyanine was studied with sensitizers, depicted on Figure 2B. ${ }^{[30,38]}$ Among tested samples (S25-p-AlPc2, S25-p-AlPc3 and S25-p-AlPc4), the S25-p-AlPc3 preparation was most active (Figure 6, curve 1). The photobactericidal activity of the photosensitizer with positively charged AlPc3 was markedly higher than the activity of the photosensitizer, bearing negatively charged AlPc4 ${ }^{[30,38]}$ This may be due to more effective interaction of the negatively charged Gram(-)-bacteria (E. coli) with positively charged dye.

Theeffect of thesupportporesize on the photobactericidal activity of the heterogeneous photosensitizers was studied for S10-p-AlPc3, S25-p-AlPc3 and S75-p-AlPc3 series. ${ }^{[32]}$ The comparative activities of sensitizers at a concentration of $4 \mathrm{~g} / \mathrm{L}$ (which is equal to the concentration of the active phase of $20 \mu \mathrm{M}$ ) showed that the white-light dose resulting in the $50 \%$ inactivation of $E$. coli pXen7 bacteria was equal to 135,156 , and $168 \mathrm{~J} / \mathrm{cm}^{2}$ for S10-p-AlPc3, S25-p-AlPc3, and S75-p-AlPc3, respectively. The reduction of the light dose upon a decrease in pore size gives evidence of an increase in the photobactericidal effect. The changes revealed are not great; however, they make it possible to conclude that the phthalocyanine located on the support surface is more active than that inside the pores.

To study the effect of the support pore size on the stability of the photobactericidal action of the heterogeneous photosensitizers, experiments with several cycles of their use were carried out. ${ }^{[32]}$ In these experiments, after the irradiation of a suspension of bioluminescent bacteria containing a photosensitizer with white light in a dose of $180 \mathrm{~J} / \mathrm{cm}^{2}$ (for $60 \mathrm{~min}$ ), the supernatant liquid with treated bacteria was separated and fresh bacteria were added to the sediment of the heterogeneous sensitizer. The suspension was incubated again for $10 \mathrm{~min}$ upon stirring and then irradiated with white light. Figure 7 illustrates a change in the photobactericidal activity of the heterogeneous sensitizers S10-p-AlPc3, S25p-AlPc3, and S75-p-AlPc3 depending on the white-light dose received in three cycles. The experiments showed that AlPc3, chemically grafted to aminopropylated silica gel has rather high photostability, with a reduction in the activity at a dose of $540 \mathrm{~kJ} / \mathrm{cm}^{2}$, corresponding to about $20 \%$ for S10-pAlPc3 and S25-p-AlPc3, and up to $10 \%$ for S75-p-AlPc3. As follows from Figure 7, the photostability of the heterogeneous photosensitizers slightly increases with an increase in the support pore size. The lowest photostability has a S10-pAlPc3 sample. It seems that phthalocyanine molecules on the support surface are prone to higher photodegradation than those inside the pores. This may be due to light scattering reducing the light dose entering the pores. 


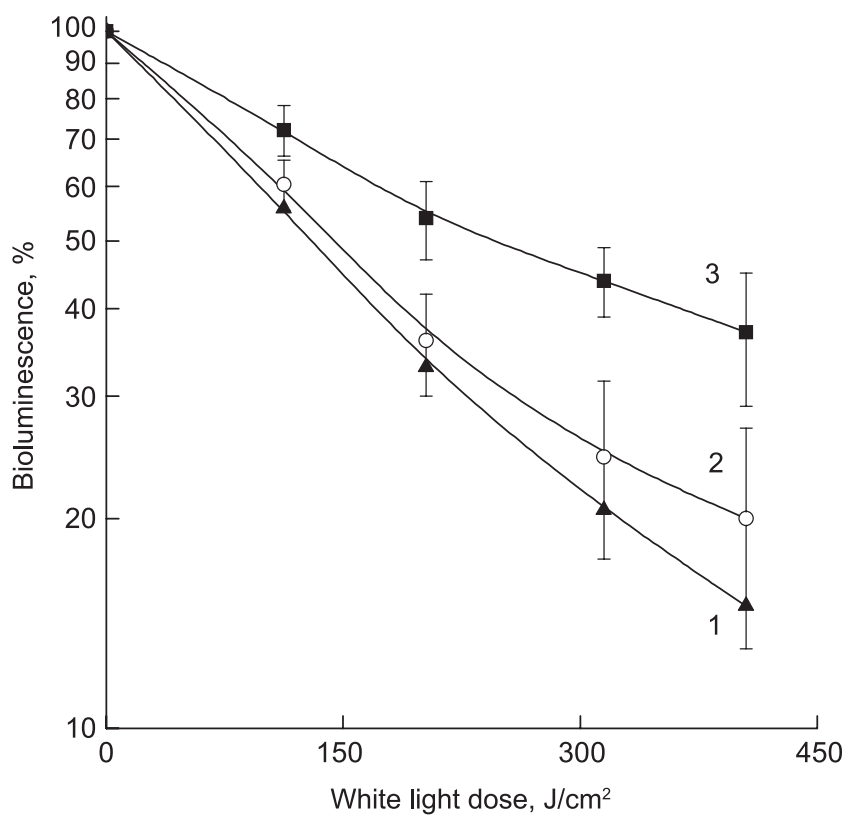

Figure 6. Quenching of E. coli pXen7 bioluminescence under irradiation by white light (halogen lamp through a water filter, $\left.\lambda_{\text {irr }} 350-700 \mathrm{~nm}, 75 \mathrm{~mW} / \mathrm{cm}^{3}\right)$ in the presence of heterogeneous photosensitizers $\left(4 \mathrm{~g} \cdot \mathrm{L}^{-1}\right)$ : 1 -S25-p-AlPc3; 2 - S25-p-AlPc2; 3 -S25-p-AlPc4. Reproduced with permission from: New heterogeneous photosensitizers with phthalocyanine molecules covalently linked to aminopropyl silica gel. N.A. Kuznetsova, O.A. Yuzhakova, M.G. Strakhovskaya, A.O. Shumarina, A.S. Kozlov, A.A. Krasnovsky, O.L. Kaliya. J. Porphyrins Phthalocyanines 2011, 15, Issues 7-8. Copyright (C) 2011 World Scientific Publishing Company.

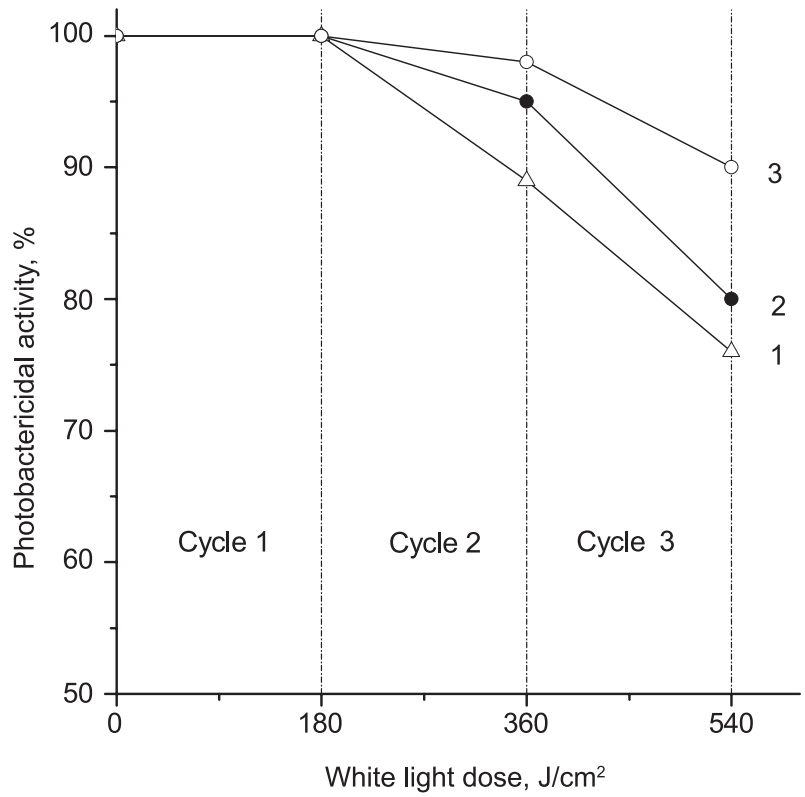

Figure 7. Changes in the photobactericidal activity of S10-pAlPc3 (1), S25-p-AlPc3 (2), and S75-p-AlPc3 (3) sensitizers towards $E$. coli $\mathrm{pXen} 7$ bacteria depending on the light dose (halogen lamp through a water filter, $\lambda_{\text {irr }} 350-700 \mathrm{~nm}$ ) (Reproduced with permission from Ref. ${ }^{[32]}$ Copyright (C) Pleiades Publishing, Ltd., 2013).
Results on the biosensor photoinactivation by heterogeneous sensitizers with different length of spacer between phthalocyanine and support ${ }^{[31,39]}$ are shown in Table 1. Figure 8 as an example illustrates the effect of spacer length on photobactericidal activity of the SiPc1, supported on S25. It is seen that the photobactericidal function of the supported SiPc1 is increased along with length of spacer. The results with SiPc1 attached to S75 and AlPc3 on S25 (Table 1) also reveal that a longer spacer chain is preferred for the immobilization of the photodynamic sensitizers onto the surface of solid support. The longer spacer chains enable the surface immobilized photosensitizers to act with a higher freedom, which is more similar to their free analogs in solution.

Table 1. The biosensor photoinactivation by heterogeneous sensitizers and white light in dose $180 \mathrm{~J} / \mathrm{cm}^{2}$ (halogen lamp through a water filter, $\lambda_{\text {irr }} 350-700 \mathrm{~nm}, 1 \mathrm{~h}$ irradiation) measured by bioluminescent test.

\begin{tabular}{cc}
\hline Sensitizer & Bioluminescence, \% to dark control \\
\hline S25-p-SiPc1 & $77 \pm 6$ \\
S25-2p-SiPc1 & $52 \pm 5$ \\
S25-4p-SiPc1 & $23 \pm 4$ \\
S75-p-SiPc1 & $48 \pm 4$ \\
S75-2p-SiPc1 & $25 \pm 3$ \\
S75-4p-SiPc1 & $10 \pm 2$ \\
S25-p-AlPc3 & $71 \pm 6$ \\
S25-2p-AlPc3 & $43 \pm 4$ \\
\hline
\end{tabular}

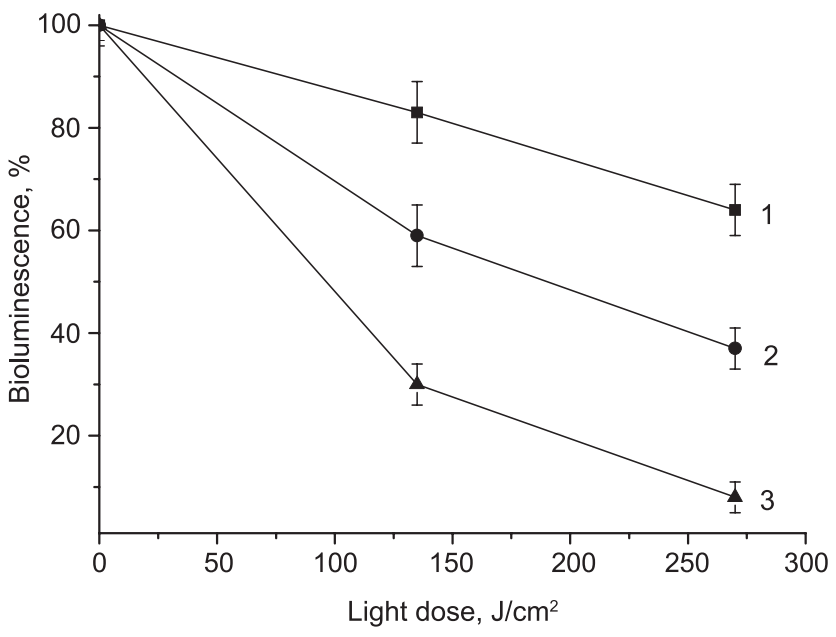

Figure 8. Quenching of E.coli K-12 TG1 (biosensor Ecolum) bioluminescence under irradiation by white light (halogen lamp through a water filter, $\left.\lambda_{\text {irr }} 350-700 \mathrm{~nm}, 50 \mathrm{~mW} / \mathrm{cm}^{2}\right)$ in the presence of heterogeneous photosensitizers $\left(4 \mathrm{~g} \cdot \mathrm{L}^{-1}\right): 1$ - S25-pSiPc1; 2 - S25-2p-SiPc1; 3 - S25-4p-SiPc1. ${ }^{[31]}$

\subsection{Photodynamic Inactivation of Viruses}

Viral contamination of water is of particular concern. Viruses as compared with bacteria are more resistant to chlorination and other common forms of water disinfection 
and have very low infectious doses. There are emerging technologies, particularly based on photodynamic effect, that show promise. The photoinactivation of viruses in aqueous environment attracted attention also due to application of photodynamic approach for the disinfection of blood products, where a considerable progress has been made. ${ }^{[40]}$

The overview of current knowledge about photodynamic inactivation of viruses with homogeneous sensitizers was given by Wainwright. ${ }^{40]}$ The photosensitizer binding with virus should help its efficient photodynamic inactivation. As was shown for bacteria, the electrostatic interactions are most important for sensitizer binding to microorganisms. It was proved that viral pathogens are inactivated effectively in water in the presence of cationic sensitizers. ${ }^{[40]}$ Inactivation of viruses by anionic and neutral photosensitizers has been also observed but this requires higher irradiation doses than for cationic ones. ${ }^{[41]}$

Although many studies on the photodynamic inactivation of bacteria with heterogeneous sensitizer have been reported, only few ones have addressed virus inactivation. Thus, for photodynamic inactivation of viruses, a suspension of fullerene $\mathrm{C}_{60}$ has been suggested. ${ }^{[19]}$ Monomeric fullerenes are known to efficiently produce singlet oxygen upon irradiation in organic media showing strong potential for photodynamic action in biological systems. Contrariwise, suspensions of aggregated fullerenes in water have very low yield of singlet oxygen. However, they retained some ability to inactivate viruses under illumination by visible light. ${ }^{[19]}$

Designed in our work heterogeneous sensitizers possess high activity in virus photoinactivation. ${ }^{[42,43]}$ Samples S10-p-AlPc3, S25-p-AlPc3 and S75-p-AlPc3 (loading of the support by the AlPc3 - $5 \mu \mathrm{mol} \cdot \mathrm{g}^{-1}$ ) were used in these studies. The poliovirus type $1 \mathrm{LSc} 2 \mathrm{ab}$ and MS2 coli phage served as model viruses. Both viruses are widely regarded as significant, frequently used in virus inactivation studies and have dimensions about $30 \mathrm{~nm}$ in diameter, ${ }^{[44-46]}$ comparable with size of pores of heterogeneous sensitizers under investigation (10, 25 and $75 \mathrm{~nm})$. Briefly, aqueous suspension of sensitizer was spiked with virus and illuminated at $20-24{ }^{\circ} \mathrm{C}$ under air bubbling conditions. Residual amount of viable virus was estimated in PFU (number of plaque-forming units on assayed plate) for coli phage and $\mathrm{TCID}_{50 / \mathrm{mL}}(50 \%$ Tissue Culture Infective Dose) for poliovirus at various irradiation times after sedimentation of sensitizer, in supernatant and in sediment separately. This approach, firstly, enabled authors to compare the ability of sensitizer to adsorb viruses, and, secondly, to study virus photoinactivation separately in two phases, liquid and sediment.

It was found that heterogeneous sensitizer alone, without light, caused drastic decrease in virus titre of liquid phase due to microorganism adsorption on sensitizer particls. ${ }^{[42]}$ The total virus amount in supernatant and sediment was close to that of control (without sensitizer) evidencing low sensitizer dark toxicity.

The distribution of poliovirus and coli phage between liquid phase and sensitizer sediment without light is shown in Table 2. Obtained data demonstrate the similarity of poliovirus and MS2 coli phage adsorption on sensitizers. Thus, in the presence of S10-p-AlPc3 and S25-p-AlPc3, viruses were found both in supernatant and in sediment. The sediment samples showed about one order of magnitude higher PFU and $\mathrm{TCID}_{50 / \mathrm{mL}}$ values when compared with supernatant. Adsorption of MS2 coli phage and poliovirus on sensitizers with 10 and $25 \mathrm{~nm}$ pore size is partial; evidently viruses are adsorbed predominantly on the surface of sensitizer particles without penetration into pores, which are too small for 28-30 nm viruses. In supernatant of S75p-AlPc3 suspension viruses were not detected (Table 2) demonstrating full adsorption for both poliovirus and MS2 coli phage. Virus was removed from water phase totally. It is obvious that in this case virus can freely penetrate into pores, and this helps adsorption. Thus, obtained results show dependence of virus adsorption upon pore size of sensitizer. Efficient adsorption demands sensitizer pore size sufficiently high to enclose virus particle.

The next series of experiments were conducted to evaluate the effects of S10-p-AlPc3, S25-p-AlPc3 and S75$\mathrm{p}$-AlPc3 exposed to visible light on viruses in liquid phase and adsorbed on sensitizer particles (Tables 3 and 4).

Table 2. Virus distribution between supernatant and sediment of heterogeneous sensitizer (without light) (adopted from Ref. ${ }^{[42]}$ ).

\begin{tabular}{ccccc}
\hline \multirow{2}{*}{ Sensitizer } & \multicolumn{2}{c}{ Coli phage MS2, PFU } & \multicolumn{2}{c}{ Poliovirus, TCID $_{50}$} \\
\cline { 2 - 5 } & $\begin{array}{c}\text { Supernatant } \\
(25 \mathrm{~mL})\end{array}$ & Sediment & $\begin{array}{c}\text { Supernatant } \\
(25 \mathrm{~mL})\end{array}$ & Sediment \\
\hline S10-p-AlPc3 & $0.20 \cdot 10^{6}$ & $1.7 \cdot 10^{6}$ & $0.15 \cdot 10^{4}$ & $1.9 \cdot 0^{4}$ \\
S25-p-AlPc3 & $0.25 \cdot 10^{6}$ & $1.9 \cdot 10^{6}$ & $0.077 \cdot 10^{4}$ & $1.7 \cdot 10^{4}$ \\
S75-p-AlPc3 & 0 & $1.9 \cdot 10^{6}$ & 0 & $1.9 \cdot 10^{4}$ \\
Control & \multicolumn{2}{c}{$2.4 \cdot 10^{6}$} & \multicolumn{2}{c}{$2.2 \cdot 10^{4}$} \\
\hline
\end{tabular}

Table 3. Activities of heterogeneous sensitizers S10-p-AlPc3, S25-p-AlPc3 and S75-p-AlPc3 for photoinactivation of the MS2 coli phage (500W halogen lamp, $\lambda_{\text {irr }} 350-700 \mathrm{~nm}$ ) (adopted from Ref. ${ }^{[42]}$ )

\begin{tabular}{cccc}
\hline Sensitizer & $\begin{array}{c}\text { Irradiation } \\
\text { time, h }\end{array}$ & $\begin{array}{c}\text { Coli phage in } \\
\text { supernatant, } \\
\text { PFU/25 mL }\end{array}$ & $\begin{array}{c}\text { Coli phage } \\
\text { in sediment, } \\
\text { PFU/10 mL }\end{array}$ \\
\hline \multirow{5}{*}{ S10-p-AlPc3 } & 0 & $1.3 \cdot 10^{3}$ & $5.6 \cdot 10^{3}$ \\
& 0.5 & 0 & $1.6 \cdot 10^{3}$ \\
& 1.0 & 0 & $6.3 \cdot 10^{1}$ \\
& 2.0 & 0 & 0 \\
\hline S25-p-AlPc3 & 0 & $0.69 \cdot 10^{3}$ & $5.7 \cdot 10^{3}$ \\
& 0.5 & 0 & $1.2 \cdot 10^{2}$ \\
& 1.0 & 0 & 0 \\
S75-p-AlPc3 & 2.0 & 0 & 0 \\
\hline Control & 0 & 0 & $6.1 \cdot 10^{3}$ \\
& 0.5 & 0 & 0 \\
\hline & 1.0 & 0 & 0 \\
\hline
\end{tabular}

As depicted in Table 3, after sensitizer addition into water, contaminated with $6.5 \cdot 10^{3} \mathrm{PFU} / 25 \mathrm{~mL}$ of MS2 coli phage, without illumination concentration of virus in liquid phase (supernatant) of S10-p-AlPc3 and S25-pAlPc3 suspensions due to adsorption falls down to $1.3 \cdot 10^{3}$ and $0.69 \cdot 10^{3} \mathrm{PFU} / 25 \mathrm{~mL}$, correspondingly. Total MS2 coli phage photoinactivation in supernatant of these samples was achieved in $0.5 \mathrm{~h}$ irradiation with visible light. Supernatant 
of S75-p-AlPc3 suspension was fully freed from phage before illumination due to extremely efficient virus adsorption on this sensitizer. Meanwhile MS2 coli phage amount of about $6 \cdot 10^{3} \mathrm{PFU}$, close to that of control, was found in sediment of all suspensions before illumination, additionally evidencing predominant virus adsorption. Total coli phage inactivation in sediment was achieved in suspensions of S10-p-AlPc3, S25-p-A1Pc3 and S75-pAlPc3 after 2, 1 and $0.5 \mathrm{~h}$ of irradiation with visible light, correspondingly. Thus, the substantial increase of MS2 coli phage photoinactivation efficiency along with sensitizer pore size was revealed (Figure 9).

Table 4. Activities of heterogeneous sensitizers S10-p-AlPc3, S25p-AlPc3 and S75-p-AlPc3 for photoinactivation of the poliovirus (500W halogen lamp, $\lambda_{\text {irr }} 350-700 \mathrm{~nm}$ ) (adopted from Ref. ${ }^{[42]}$ ).

\begin{tabular}{cccc}
\hline Sensitizer & $\begin{array}{c}\text { Irradiation } \\
\text { time, } \mathrm{h}\end{array}$ & $\begin{array}{c}\text { Poliovirus in } \\
\text { supernatant, } \\
\text { TCID }_{50} / 25 \mathrm{~mL}\end{array}$ & $\begin{array}{c}\text { Poliovirus } \\
\text { in sediment, } \\
\text { TCID }_{50} / 10 \mathrm{~mL}\end{array}$ \\
\hline & 0 & $1.5 \cdot 10^{3}$ & $1.7 \cdot 10^{4}$ \\
S10-p-AlPc3 & 0.5 & $1.7 \cdot 10^{2}$ & $5.9 \cdot 10^{3}$ \\
& 1.0 & $2.8 \cdot 10^{1}$ & $5.9 \cdot 10^{2}$ \\
& 2.0 & 0 & 0 \\
\hline S25-p-AlPc3 & 0 & $7.7 \cdot 10^{2}$ & $1.7 \cdot 10^{4}$ \\
& 0.5 & $4.5 \cdot 10^{1}$ & $5.9 \cdot 10^{2}$ \\
& 1.0 & 0 & $1.4 \cdot 10^{2}$ \\
S75-p-AlPc3 & 2.0 & 0 & 0 \\
\hline Control & 0 & 0 & $1.9 \cdot 10^{4}$ \\
& 0.5 & 0 & $1.4 \cdot 10^{2}$ \\
& 1.0 & 0 & $1.1 \cdot 10^{1}$ \\
\hline
\end{tabular}

Data on poliovirus photoinactivation by heterogeneous sensitizers are presented in Table 4 and Figure 10. The initial level of water contamination with poliovirus in these experiments was $2.2 \cdot 10^{4} \mathrm{TCID}_{50} / 25 \mathrm{~mL}$. In agreement with results on virus adsorption, poliovirus was not found in supernatant of S75-p-AlPc3 suspension after sensitizer addition both without light and after $0.5-2 \mathrm{~h}$ of irradiation.

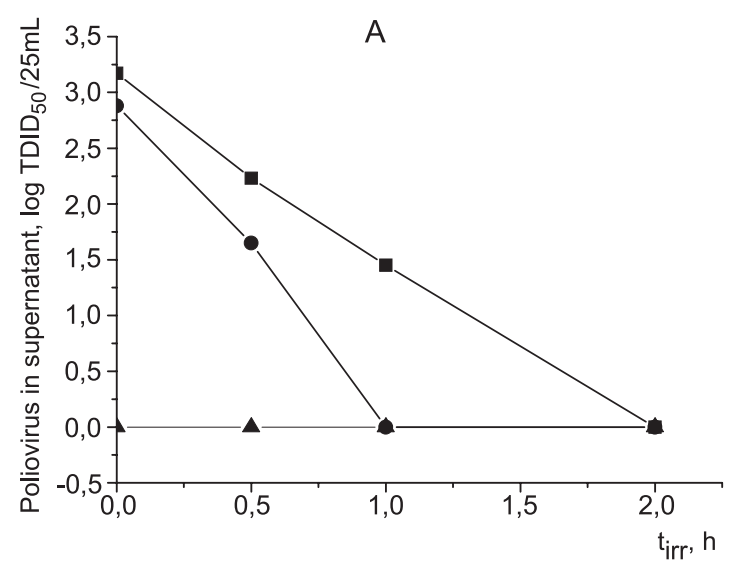

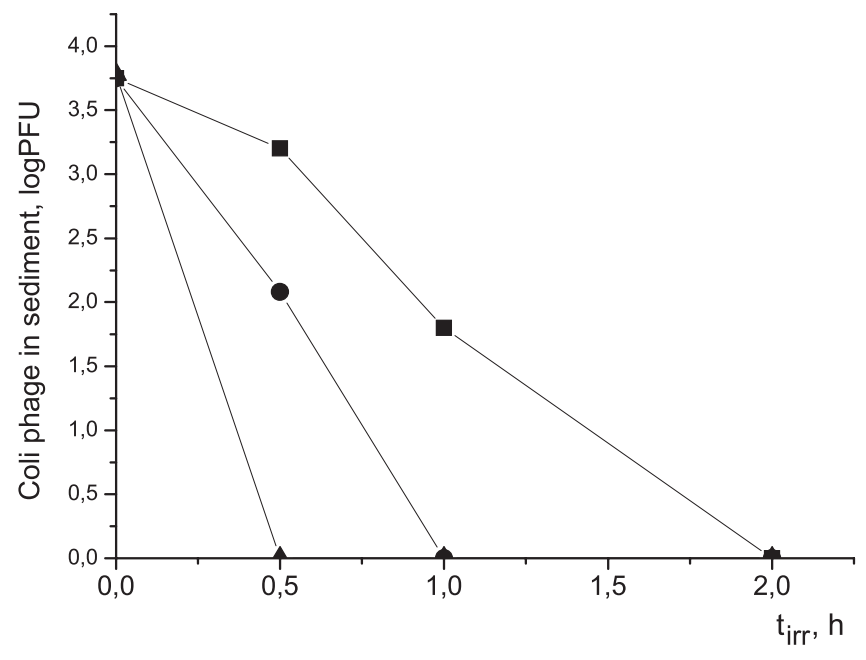

Figure 9. Coli phage survival in sediment of S10-p-

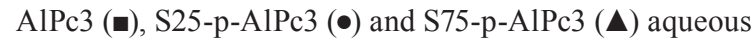
suspensions under irradiation with visible light $(500 \mathrm{~W}$ halogen lamp, $\lambda_{\text {irr }} 350-700 \mathrm{~nm}$ ). Reproduced with permission from: Effect of the support pore size upon antiviral activity of the heterogeneous photosensitizer with phthalocyanine covalently linked to aminopropyl silica gel. N.A. Kuznetsova, O.A. Yuzhakova, A.E. Netdachin, R.A. Dmitrieva, T.V. Doskina, T.N. Maksimkina, O.L. Kaliya. J. Porphyrins Phthalocyanines 2013, 17, Issues 8-9. Copyright (C) 2013 World Scientific Publishing Company.

The poliovirus inactivation in supernatant of S10-pAlPc3 and S25-p-AlPc3 suspensions required 2 and $1 \mathrm{~h}$ of photodynamic treatment (Figure 10). Results on poliovirus survival in sediment of S10-p-AlPc3, S25-p-AlPc3 and S75p-AlPc3 aqueous suspensions under irradiation with visible light (Figure 10) show obvious dependence of sensitizer efficiency on its pore size. The relationship is like observed for MS2 coli phage photoinactivation: the most efficient was sensitizer S75-p-AlPc3, capable to enclose virus into the pore cavity. Sample S25-p-AlPc3 has intermediate efficiency. Due to pore size inhomogeneity, this sample has the greater

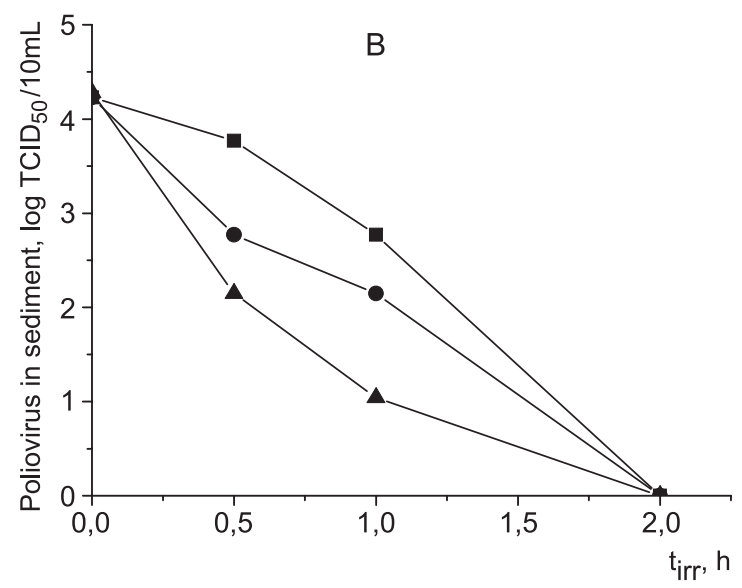

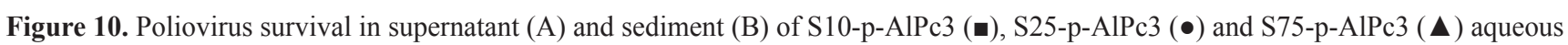
suspensions under irradiation with visible light (500W halogen lamp, $\lambda_{\text {irr }} 350-700 \mathrm{~nm}$ ). Reproduced with permission from: Effect of the support pore size upon antiviral activity of the heterogeneous photosensitizer with phthalocyanine covalently linked to aminopropyl silica gel. N.A. Kuznetsova, O.A. Yuzhakova, A.E. Netdachin, R.A. Dmitrieva, T.V. Doskina, T.N. Maksimkina, O.L. Kaliya. J. Porphyrins Phthalocyanines 2013, 17, Issues 8-9. Copyright (C) 2013 World Scientific Publishing Company. 
fraction of large-size pores, fitting virus dimensions, than S10-p-AlPc3. Poliovirus seems to be more resistant to photoinactivation than coli phage. Thus, notwithstanding poliovirus total killing in suspentions of all investigated sensitizers in two hours, coli phage photoinactivation by S75-p-AlPc3 and S25-p-AlPc3 was completed in shorter time periods: 0.5 and $1 \mathrm{~h}$, respectively.

\section{Conclusions}

New heterogeneous sensitizers with photobactericidal and photovirucidal activity have been synthesized by grafting of bulky substituted phthalocyanines of $\mathrm{Zn}, \mathrm{Al}$ and $\mathrm{Si}$ to aminopropyl silica gel. Absorption and emission spectra show low aggregation degree of immobilized phthalocyanines, which also retain ability for singlet oxygen generation. The charge of attached phthalocyanine, support pore size and length of spacer between dye and silica are the key factors governing efficacy of heterogeneous sensitizers in photodynamic microorganism inactivation.

The inverse effect of heterogeneous sensitizer pore size upon photoinactivation of bacteria and viruses was found: the pore size increase from 10 to 25 and $75 \mathrm{~nm}$ results in moderate decrease of the bacteria $E$. coli photoinactivation, meanwhile the photovirucidal activity grows substantially. This difference was explained by consideration of dye, bacteria and virus localization - on surface or in pores of support. The most efficient photoinactivation occurs if both active phase of sensitizer (phthalocyanine) and microorganism are in close proximity. This condition is fulfilled for bacteria and phthalocyanine on the surface of S10 silica, since both of them cannot penetrate into $10 \mathrm{~nm}$ pores. In case of S25 and S75 supports Pc is predominately located inside the pores, whereas spacious bacteria remain on the surface of particle, and photoinactivation goes down. The model viruses, used in studies (poliovirus type $1 \mathrm{LSc} 2 \mathrm{ab}$ and MS2 coli phage), have dimensions about $30 \mathrm{~nm}$ in diameter ${ }^{[4-46]}$ and can enter into pores of S75 support, where they meet sensitizer (phthalocyanine) and are efficiently killed by generated singlet oxygen and other active oxygen species.

The fluorescence and generation of singlet oxygen are higher for the systems having dye molecules on the support surface rather than inside the pores. Probably this effect is associated with light scattering from the surface of silica gel reducing the light dose penetrating the pores.

The photobactericidal function of the supported phthalocyanines was markedly increased along with length of spacer between sensitizing dye and support. The longer spacer chains enable the surface immobilized photosensitizers to act with a higher freedom, which is more similar to their free analogs in solution.

Thus, high potential of suggested by us heterogeneous photosensitizers as antimicrobial agents was demonstrated. Additional advantage of these materials is their accessibility. Such materials could find different applications, and are open for new investigations.

Acknowledgements. This work was supported by the Russian Foundation for Basic Research (project Nos 13-0300667 and 13-03-12094).

\section{References}

1. DeRosa M.C., Crutchley R.J. Coord. Chem. Rev. 2002, 233/234, 351-371.

2. Kuznetsova N.A., Kaliya O.L. Ross. Khim. Zh. 2013, LVII, N 2, 100-109 (in Russ.).

3. Mantareva V.N., Angelov I., Wöhrle D., Borisova E., Kussovski V. J. Porphyrins Phthalocyanines 2013, 17, 399-416.

4. Krasnovsky A.A.,Jr. Biochem. (Moscow) 2007, 72, 1065-1080.

5. Schmidt R. Photochem. Photobiol. 2006, 82, 1161-1177.

6. Wöhrle D., Suvorova O., Gerdes R., Bartels O., Lapok L., Baziakina N., Makarov S., Slodek A. J. Porphyrins Phthalocyanines 2004, 8, 1020-1041.

7. Skurlatov Y.I., Ernestova L.S., Vichutinskaya E.V., Samsonov D.P., Semenova I.V., Rod'ko I.Ya., Shvidky V.O., Pervunina R.I., Kemp T.J. J. Photochem. Photobiol. A: Chem. 1997, 107, 207-213.

8. Cai J.-H., Huang J.-W., Zhao P., Zhou Y.-H., Yu H.-C., Ji L.-N. J. Mol. Catal. A: Chem. 2008, 292, 49-53.

9. Hamblin M.R., Hasan T. Photochem. Photobiol. Sci. 2004, 3, 436-450.

10. Redmond R.W., Gamlin J.N. Photochem. Photobiol. 1999, 70, 391-475.

11. Kuznetsova N. Sensitization of Singlet Oxygen Formation in Aqueous Media. In: Photosensitizers in Medicine, Environment, and Security (Nyokong T., Vefa A., Eds.). Springer Science, 2012. pp. 271-318.

12. Blossey E.C., Neckers D.C., Thayer A.L., Schaap A.P. J. Am Chem. Soc. 1973, 95, 5820-5822.

13. Jori G., Fabris C., Soncin M., Ferro S., Coppellotti O., Dei D., Fantetti L., Chiti G., Roncucci G. Lasers in Surgery and Medicine 2006, 38, 468-481.

14. Mosinger J., Losinska K., Abramova T., Veiserova S., Micka Z., Nemcova I., Mosinger B. Anal. Lett. 2000, 33, 1091-1104.

15. Krouit M., Granet R., Krausz P. Bioorg. Med. Chem. 2008, 16, 10091-10097.

16. Bonnett R., Krysteva M.A., Lalov I.G., Artarsky S.V. Water Research 2006, 40, 1269-1275.

17. Magaraggia M., Jori G., Soncin M., Schofield C., Russell D. Photochem. Photobiol. Sci. 2013, 12, 2170-2176.

18. CORDIS focus RTD Results Supplement. Polymeric support to water disinfection by singlet oxygen generation. 2007, 66, 16.

19. Belousova I.M., Danilov O.B., Muravieva T.D., Kislyakov I.M., Rilkov V.V., Krisko T.K., Kiselev O.I., Zarubaev V.V., Sirotkin A.K., Piotrovskii L.B. Opt. Zh. (J. Optical Technology) 2009, 76(4), 97-107 (in Russ.).

20. Nyokong T. Coord. Chem. Rev. 2007, 251, 1707-1722.

21. Ishii K. Coord. Chem. Rev. 2012, 256, 1556-1568.

22. Ishii K., Kobayashi N. The Photophysical Properties of Phthalocyanines and Related Compounds. In: The Porphyrin Handbook, Vol. 16 (Kadish K.M., Smith K.M., Guilard R., Eds.), San Diego, Academic Press, 2003. p. 1-42.

23. Strakhovskaya M.G., Zarubina A.P., Zhuhovitsky V.G., Mironov A.F., Rubin A.B. Doklady RAS 2004, 396, 177-180 (in Russ.).

24. Merchat M., Bertolini G., Giacomini P., Villanueva A., Jori G. J. Photochem. Photobiol. B: Biology 1996, 32, 153-157.

25. Bertoloni G., Salvato B., Dall'Acqua M., Vazzoler M., Jori G. Photochem. Photobiol. 1984, 39, s1, 811-816.

26. Sukupolvi S., Vaara M. Biochim. Biophys. Acta 1989, 988, 377-387.

27. Lambrechts S.A., Aalders M.C., Langeveld-Klerks D.H., Khayali Y., Lagerberg J.W. Photochem. Photobiol. 2004, 79, 297-302.

28. George R.D., Snow A.W., Shirk J.S., Barger W.R. J. Porphyrins Phthalocyanines 1998, 2, 1-7.

29. Esenpinar A.A., Durmus M., Bulut M. J. Photochem. Photobiol. A: Chem. 2010, 213(2-3), 171-179. 
30. Kuznetsova N.A., Yuzhakova O.A., Strakhovskaya M.G., Shumarina A.O., Kozlov A.S., Krasnovsky A.A., Kaliya O.L. J. Porphyrins Phthalocyanines 2011, 15, 718-726.

31. Kuznetsova N.A., Yuzhakova O.A., Strakhovskaya M.G., Slivka L.K., Kaliya O.L., Lukyanets E.A. Macroheterocycles 2013, 6, 363-370.

32. Kuznetsova N.A., Yuzhakova O.A., Kozlov A.S., Krasnovskii A.A., Strakhovskaya M.G., Kaliya O.L. Nanotechnologies in Russia 2013, 8, 122-128.

33. Kuznetsova N.A., Makarov D.A., Yuzhakova O.A., Solovieva L.I., Kaliya O.L. J. Porphyrins Phthalocyanines 2010, 14, 968-974.

34. Jensen F., Greer A., Clennan E.L. J. Am. Chem. Soc. 1998, 120 , 4439- 4449.

35. Pomelli C.S., Chiappe C., Lapi A. J. Photochem. Photobiol. A: Chem. 2012, 240, 59-65.

36. Zinkovskaya O.V., Kuznetsova N.A., Reznichenko A.V. Khimiya Vysokikh Energiy 1987, 21, 352-355 (in Russ.).
37. Krasnovsky A.A. Membrane and Cell Biology (Biologicheskie Membrany) 1998, 12, 665-690.

38. Patent RF 2447 027, 2012.

39. Patent RF 2558 261, 2014.

40. Wainwright M. Photochem. Photobiol. Sci. 2004, 3, 406-411.

41. Casteel M.J., Jayaraj K., Gold A., Ball L., Sobsey M. Photochem. Photobiol. B 2004, 80, 294-300.

42. Kuznetsova N.A., Yuzhakova O.A., Netdachin A.E., Dmitrieva R.A., Doskina T.V., Maksimkina T.N., Kaliya O.L. J. Porphyrins Phthalocyanines 2013, 17, 772-777.

43. Patent RF 2470 051, 2012.

44. Strauss J.H., Sinsheimer R.L. J. Mol. Biol. 1963, 7, 43-54.

45. Kitamura N., Semler B., Rothberg P., Larsen G.R., Adler C.J., Dorner A.J., Emini E.A., Hanecak R., Lee J., Werf S., Carl W., Anderson C.W., Wimmer E. Nature 1981, 291, 547-553.

46. Hogle J. Annu. Rev. Microbiol. 2002, 56, 677-702.

Received 24.12.2014

Accepted 06.01.2015 